\title{
Sıçan primer nöron kültüründe glutamat eksitotoksisitesine karşı nar kabuğu ekstresinin etkileri
}

\section{Effects of pomegranate peel extract against glutamate excitotoxicity in rat primary neuron culture}

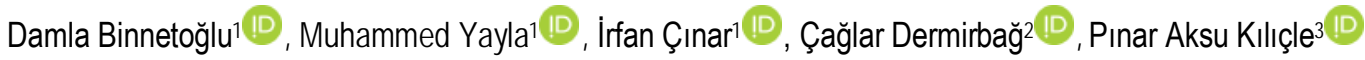 \\ 1 Kafkas Üniversitesi, Tıp Fakültesi, Tıbbi Farmakoloji AD, Kars, Türkiye \\ ${ }^{2}$ Trakya Üniversitesi, Eczacilık Fakültesi, Analitik Kimya AD, Edirne, Türkiye \\ ${ }^{3}$ Kafkas Üniversitesi, Fen Fakültesi, Moleküler Biyoloji AD, Kars, Türkiye
}

Öz.

Amaç: Güçlü bir antioksidan etkiye sahip olan nar kabuğunun pek çok fizyolojik özellikleri gösterilmiştir. Çalışmamızda eksitatör bir nörotransmitter olan glutamatın nörotoksik etkisine karşı, güçlü antioksidan olan nar kabuğunun etkilerini araştırmayı amaçladık.

Materyal ve Metot: Çalışmamızda yeni doğan sıçan beyin korteksi kullanılmıştır. Nar kabuğu ekstresi 200, 300 ve $400 \mathrm{mg} / \mathrm{ml}$ dozunda uygulandıktan 2 saat sonra $6 \times 10^{-3}$ ve $3 \times 10^{-3} \mathrm{M}$ konsantrasyonda glutamat uygulaması gerçekleştirildi. Toksisite oluşturulduktan 24 saat sonra canlılık testi, total oksidan ve antioksidan kapasite ölçümleri gerçekleştirildi.

Bulgular: Glutamat uygulaması artan dozlarda hücre canlıı̆̆ını önemli ölçüde azaltırken nar kabuğu ekstresi yüksek dozda en iyi nöroprotektif etkiyi ortaya koymuştur. Toksisiteye bağlı artan oksidan kapasite nar kabuğu uygulaması ile anlamlı derecede düzelmiştir. Glutamata bağlı azalan antioksidan kapasite nar kabuğu ekstresi ile düzelme göstermiştir. Nar kabuğu ekstresi tek başına yüksek doz uygulandığında proliferatif etki ortaya koymuştur. Nar kabuğu nöroprotektif etkilerini proinflamatuar sitokin olan tümör nekrozis faktör-a ve apoptotik proteinler olan caspas 3 ve 9 ekspresyonunu baskılayarak ortaya koymuştur.

Sonuç: Nar kabuğu ekstresi antioksidan, antiinflamatuar ve anti-apoptotik etkisi ile glutamata bağlı gelişen nörotoksisiteyi önlemiştir.

Anahtar Kelimeler: Nar, Eksitotoksisite, Glutamat, Sıçan

\section{Abstract}

Background: Many physiological properties of pomegranate peel which has a strong antioxidant effect have been shown. We aimed to investigate the effects of pomegranate peel, a potent antioxidant on the neurotoxic effect of glutamate, an excitatory neurotransmitter.

Methods: In our study, the newly born rat brain cortex was used. Pomegranate peel extract were used 200, 300 and $400 \mathrm{mg} / \mathrm{ml}$ dose after 2 hours $6 \times 10^{-3}$ and $3 \times 10^{-3} \mathrm{M}$ concentration glutamate application was performed. After 24 hours of toxicity, viability test, total oxidant and antioxidant capacity measurements were performed.

Results: Glutamate application significantly reduced cell viability in increased doses, while pomegranate peel extract revealed the best neuroprotective effect in high doses. Increased total oxidant capacity due to toxicity has been significantly improved with pomegranate peel application. Decreased antioxidant capacity due to glutamate has improved with pomegranate peel extract. Pomegranate peel extract alone had a proliferative effect when high doses were applied. The pomegranate peel has demonstrated its neuroprotective effects by suppressing the proinflammatory cytokine tumor necrosis factor-a and the expression of apoptotic proteins, caspase 9 and 3 .

Conclusion: Pomegranate peel extract inhibited glutamate-induced neurotoxicity due to its antioxidant, anti-inflammatory and anti-apoptotic effect.

Key Words: Pomegranate, Excitotoxicity, Glutamate, Rat
Sorumlu Yazar I

Corresponding Author

Dr. Damla BINNETOĞLU

Kafkas Üniversitesi, Tıp Fakültesi,

Tıbbi Farmakoloji AD,

Kars, Türkiye

Tel: +90 (474) 2317648

E-mail: damlacetin.erz@gmail.com

Geliş tarihi / Received: 21.12.2018

Kabul tarihi / Accepted: 22.07.2019

Bu çalışmanın bir bölümü

V. Uluslararası Multidisipliner

Çalışmaları Sempozyumunda (ISMS)

sözlü olarak sunulmuştur

(16-17 Kasım 2018, Ankara-Türkiye).

DOI: 10.35440/hutfd.500521 


\section{Giriş}

Nar, Kınagiller familyasına dahil olup Punica Granatum cinsinden çok yıllık bir bitkidir. Nar 5000 yıldır yetiştirildiği bilinen ticari, kültürel ve terapötik öneme sahip bir meyvedir (1). Nar meyvesinin kabuğu, çekirdeği ve meyvesi ayrı ayrı yıllardır terapötik amaçla kullanımaktadır. Özellikle nar kabuğu başta flavanoidler (antosiyanin, kateşin ve diğer kompleks flavanoidler) ve tanenler (punikalin, punikalagin, gallik asit ve ellagik asit) olmak üzere fenolik bileşenlerce zengindir (2). Fenolik bileşenler ise antioksidan aktivite gösteren doğal bileşenlerdir. Antioksidan aktivite gösteren bileşiklerce zengin besinler ile beslenmenin, serbest radikallerden kaynaklanan kanser, kalp-damar hastalıkları, diyabet ve nörolojik hastalıkları önleme konusunda fayda sağladığı bilinmektedir. Antioksidanlar, inflamasyon ve immün yanıtı modüle ederek söz konusu hastalıklara karşı koruyucu etkinlik göstermektedirler (3-8). Narın bir diğer önemli etkisi olan antimutajenik etkisinin, kabuğunda bulunan ellagik asit, ellagitanninler ve gallik asitlerden kaynaklanabileceği belirtilmiştir (9). Gallik asit, ellagik asit ve punikalagin, antioksidan aktivitelerine ilave olarak enterik patojenlere karşı antibakteriyel etkiye de sahiptirler. (2). Narın antibakteriyel etkinliğinin araştıııldığı çalışmalarda başlıca etken maddenin punikalagin olduğu da vurgulanmıştır. Çalışma sonucunda narın deri enfeksiyonlarında antifungal olarak kullanım açısından terapötik/iyileştirici bir alternatif olabileceği belirtilmiştir (10).

Glutamat plazma membran depolarizasyonu ile $\mathrm{Ca}^{++}$un hücre içine girişine, nitrik oksit sentaz gibi serbest radikal oluşturan sistemlerin aktivasyonuna ve sonuç olarak oksidatif strese bağlı olarak nöral ve glial ölüme neden olur. Hücrede $\mathrm{Ca}^{++}$artışı lipolitik enzimleri aktive eder. Bu enzimler nöron membranındaki fosfolipidlerden araşidonik asit salınımına neden olur. Serbest radikal ve lipid peroksidleriyle nöronun ölümüne kadar sürer (11). İskemik beyin hasarı, hipoglisemik beyin hasarı, epilepsi, kafa travması ve toksik ensefalopatiler gibi bazı nörolojik hastalıkların oluşumunda glutamat eksitotoksisitenin rolü bulunmaktadır (12). Bu yüzden glutamata bağlı toksisitenin önlenmesi ayrı bir öneme sahiptir. Ancak günümüzde halen glutamata bağlı gelişen eksitotoksisitenin önlenmesinde spesifik bir tedavi bulunmamaktadır. Bu yüzden çalışmamızda güçlü antioksidan etkinliği olan nar kabuğunun glutamata bağlı gelişen nörotoksisite üzerindeki etkilerini biyokimyasal ve moleküler mekanizmalar ile ortaya koymayı amaçladık.

\section{Materyal ve Metot \\ Ekstrenin hazırlanması}

Punica Granatum (Nar), ülkemizde hicaz narı olarak bilinen türü Mersin ilinden 2016 yılında temin edilmiştir.

Nar kabuğu ekstresi (PPE), Clevenger (Wisd-Wise Therm) cihazında, su buharı distilasyonu yöntemiyle elde edildi. Bu amaçla meyveler gölgede kurutulduktan sonra kabukları ayrıldı. $160 \mathrm{~g}$ bitki parçalayıcıda ince toz haline getirildi. Ögütülen örnek cam balon içerisine konularak üzerine $1600 \mathrm{ml}$ distile su ilave edildikten sonra Clevenger cihazına yerleştirilip cihaz çalıştıııldı. Buharlaşma başladıktan sonra üç saat süre boyunca bekletildi. Bu süre boyunca Clevengerin toplama borusunda biriken hidrosol steril edilmiş ayrı bir şişeye alındı. Bu sürenin sonunda toplama borusunda biriken son hidrosolde alındıktan sonra, geriye kalan ekstre kullanıııncaya kadar koyu renkli şişelerde, ağzı kapalı olarak, $+4^{\circ} \mathrm{C}$ 'de buzdolabında muhafaza edildi.

Ekstrede bulunan maddelerin HPLC-DAD ile analizi

Ekstrede gallik asit, ellajik asit ve punikalajin A ve B maddeleri tespit edildi ve miktar tayinleri Agilent 1200 Serisi HPLC-DAD cihazında yapıldı (Tablo 1).

Tablo $1.1 \mathrm{~g}$ ekstrede bulunan madde miktarı

\begin{tabular}{cc}
\hline Madde Adı & Miktarı (mg/g) \\
\hline Gallik Asit & $14.45 \pm 0.53$ \\
Punikalajin A & $191,56 \pm 0.36$ \\
Punikalajin B & $189,48 \pm 0.62$ \\
Ellajik Asit & $68.02 \pm 0.42$ \\
\hline
\end{tabular}

\section{Örnek hazırlama}

Sabit tartıma getirilen ekstre, konsantrasyonu $1 \mathrm{mg} / \mathrm{mL}$ olacak şekilde metanol ile çözüldü ve stok çözelti elde edildi. 10000 rpm'de 5 dakika santrifüjlendi. Elde edilen süpernatantt fosfat tamponu ( $\mathrm{pH}=2,5,0,025 \mathrm{M}$ ) ile seyreltilerek çaış̧ma çözeltileri hazırlandı. Çalışma çözeltileri enjeksiyon filtresinden geçirildikten sonra sisteme enjekte edildi. Her enjeksiyon üçer kez tekrarlandı.

\section{Etik kurul izinleri ve hayvanların temini}

Çalışmanın etik kurallara uygunluğu Kafkas Üniversitesi Hayvan Deneyleri Yerel Etik Kurulu (KAÜ-HADYEK) tarafından onaylanmıştır (HADYEK 2017-003). Deneysel hayvan laboratuvarından temin edilen toplam 10 adet yeni doğan Spraque Dawley cinsi sıçanlar kullanıldı.

\section{Primer Nöron Kültürünün Hazırlanması}

Yeni doğan Sprague Dawley cinsi sıçan yavruları hızı bir şekilde dekapite edildikten sonra korteks nöronları alınarak 1:1 tripsin ilave edildi ve inkübatörde 30 dakika süreyle bekletildikten sonra 3 defa santrifüj yapılıp ve her defasında süpernatant atıldı ve yeni medyum ilave edildi. Ayrı bir tüpte nörobasal medyum 1000:1 penisilin 50:1 B27 supplement ve 10:1 fetal bovine serum ilave edilerek medyum hazırlandı. Hazırlanan medyumun içine hücreler eklendi. 96 kuyucuklu plate'in her odacığına $150 \mu$ l medyum eklendi. Hücrelerin odacıkların tabanına yapışması ve tabanını kaplaması ve büyümesi için 10 gün enkübatörde bekletildi (13).

İlaç Uygulaması

Her grupta 10 well olacak şekilde gruplar aşağıdaki şekilde 
dizayn edilerek kurulan korteks primer kültürüne $6 \times 10^{-3} \mathrm{M}$ ve $3 \times 10^{-3} \mathrm{M}$ glutamat uygulanarak toksisite oluşturuldu. Toksisite oluşturulmadan 2 saat önce 200, 300 ve 400 $\mathrm{mg} / \mathrm{ml}$ dozunda PPE uygulandı.

\section{Gruplar:}

$$
\begin{aligned}
& \text { Grup } 1 \text { - Saf kontrol }
\end{aligned}
$$

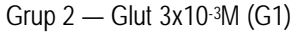

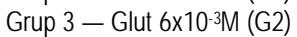

$$
\begin{aligned}
& \text { Grup 4 - PPE } 200 \mathrm{mg} / \mathrm{ml} \text { (PPE2) } \\
& \text { Grup } 5 \text { - PPE } 300 \mathrm{mg} / \mathrm{ml} \text { (PPE3) } \\
& \text { Grup } 6 \text { - PPE } 400 \text { mg/ml (PPE4) }
\end{aligned}
$$

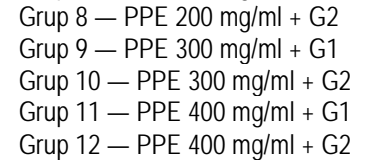

\section{Hücre canlıığı testi}

İlaç uygulamasından 24 saat sonra hücre canlilığın belirlenmesi amaciyla MTT (3-(4,5-dimethylthiazol-2-yl)-2,5diphenyltetrazolium bromide) proliferasyon kiti (CAYMAN10009365) ile ölü/canlı hücre sayısı ortaya kondu. Hücrelere glutamat uygulandıktan 24 saat sonra kitte yer alan direktiflere uygun bir şekilde ölçüm yapıldıktan sonra her bir numunenin absorbansı 570 nm'de mikroplate okuyucu kullanılarak ölçüldü.

\section{Oksidatif stresin belirlenmesi}

Toksisite uygulamasından 24 saat sonra hücre medyumları toplanarak total oksidan düzeyi (TOD) belirlemek amacıyla ticari TOD kiti (RELASSAY-Mega02) kullanılmıştır. Diğer yandan nar kabuğu ekstresinin, glutamat toksisitesinde, primer nöron kültür hücreleri üzerindeki total antioksidan kapasitesini (TAK) belirlemek amacıyla ticari TAK kiti (RELASSAY-Mega01) kullanılmıştır.Hücrelere glutamat uygulandıktan 24 saat sonra medyumlar toplanarak TAK ve TOD ölçümü yapıldı. Çalışmadan en iyi belirlenen sonuçlar arasında karşıllaştırma yapıldı (14).

\section{Moleküler analizler}

Çalışmamızda Qiagenrat taqman problu caspas 3, caspas 9 ve TNFa mRNA ekspresyon düzeyleri gruplar arasında karşılaştırıldı. Çalışmadan en iyi belirlenen sonuçlar arasında karşılaştırma yapıldı.

Hücrelerden RNA ekstraksiyonu ve cDNA sentezi:

Önceki yapmış olduğumuz çalışmalardaki direktiflere uygun bir şekilde hücrelere glutamat uygulandıktan 24 saat sonra hücreler kazınarak RNA izolasyonu (Qiagen RNaeasy mini kit-74104)ve cDNA sentezi (Qiagen RT-HT First Strand CDNA sentezi kiti-330404) gerçekleştirilmiştir.

Real-Time PCR ile mRNA ekspresyonlarının kantitatif olarak belirlenmesi

Caspase 9, caspase 3 ve TNF-a mRNA ekspresyonu, Taq Man Gene Expression Master Mix kiti kullanılarak kantifiye edildi. Amplifikasyon ve kantifikasyon işlemi StepOne Plus Real Time PCR System (Applied Biosystems) cihazinda yapıldı. 100ng cDNA için TaqMan® Gene Expression Assays'ler pipetlendi ve 40 siklus ile yürütüldü. Cycle thres-

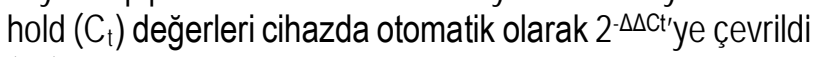
(15).

\section{İstatistiksel Analizler}

Çalışmamızın verileri IBM 21.00 SPSS paket programı ile istatistiksel olarak değerlendirildi. Gruplar arasındaki anlamlıık için One Way ANOVA çoklu karşılaştırma testinden
Tukey testine göre yapıldı. Şekillerde sütunlardaki harfler birbirinden farklı ise aralarında anlamlı bir fark vardır, harfler birbiri ile aynı ise aralarındaki fark anlamsızdır. Analiz için ortalama ve standart sapma değerleri kullanıldı. $p<0,05$ anlamlı kabul edildi.

\section{Bulgular HPLC sonuçları}

Tablo 1'de görüldüğü gibi nar kabuğu yüksek miktarda punikalagin A ve B intiva etmektedir. Aynı zamanda nar kabuğunda güçlü antioksidan biyoaktif maddelerden gallik asit ve ellajik asit yeterli miktarda bulunmaktadır.

\section{Hücre Canlıığı Bulguları}

Glutamatın yüksek doz uygulaması ile düşük doz glutamata ve kontrole göre istatistiksel olarak fark oluşturacak şekilde primer nöronlarda hücre canlılığının azaldığı belirlenmiştir $\left({ }^{*} p<0,05\right)$ (Şekil 1A). PPE uygulamasının istatistiksel olarak herhangi bir toksik etki göstermediği görülmüştür, aynı zamanda PPE4 proliferatif etki ortaya koymuştur $\left({ }^{*} p<0,05\right)$ (Şekil 1B).Kontrol grubuna göre düşük doz glutamat uygulanmış grup ve düşük doz glutamat toksisitesine karşı düşük doz PPE (PPE2) uygulanmış grupta istatistiksel olarak anlamlı fark oluşturacak düzeyde hücre canlılığı azaldığı görülmüştür. Düşükdoz glutamat toksisitesinekarşı tüm PPE dozları incelendiğinde sadece yüksek doz PPE'nin (PPE4) istatistiksel olarak hücre canlıı̆̆ını artırarak toksisiteyi önleyebildiği göze çarpmaktadır $\left({ }^{*} p<0,05\right)($ Şekil $2 A)$. Kontrol grubuna göre yüksek doz glutamat ve yüksek doz glutamata ilaveten düşük doz PPE uygulanmış gruplarda istatistiksel olarak anlamlı fark oluşturarak hücre canlılığı azalmıştır $\left({ }^{* *} p<0,01\right)\left({ }^{*} p<0,05\right)$. Ancak yüksek doz glutamat uygulamasına göre PPE uygulanan gruplar kıyaslandığında PPE3 ve PPE4 uygulanan grupların istatistiksel olarak fark oluşturarak toksisiteyi önlediği görülmüştür $(+p<0,05)$ (Şekil 2B).

\section{Oksidatif Stres Bulguları}

TOD seviyeleri incelendiğinde kontrole göre yüksek doz glutamatın anlamlı bir artışa neden olduğu görülmüştür. $\left({ }^{*} p<0,05\right)$. Glutamat uygulanan gruba göre kıyaslandığında sadece PPE4 uygulanmış grubun istatistiksel olarak fark oluşturduğu $(++p<0.01)$ görülürken glutamat ve PPE4 uygulanmış grupta da istatistiksel fark görülmüştür $(+p<0,05)$ (Şekil 3A). PPE4 uygukaması ile glutamat toksisitesine bağılı oluşan oksidan kapasite artışının geri çevrilmesinin yanı sıra PPE4 uygulamasının tek başına uygulandığında da oksidan kapasitede azalmaya yol açıı̆ı görülmüştür. Total antioksidan kapasite analizlerinde belirlenen sonuçlara göre yüksek doz glutamat uygulaması ile TAK seviyesi kontrole göre anlamlı derecede azalmıştır $\left({ }^{* *} p<0,01\right)$. Bu azalma yüksek doz PPE4 ile geri çevrilmiştir $\left({ }^{*} p<0,05,+p<0,05\right)$ (Şekil 3B).

\section{TNF-a mRNA ekspresyon düzeyleri}

Gluatmat ile indüklenen nörotoksistenin mekanizmasında inflamasyonun rolünü gösterebilmek için TNF-a seviyeleri 
ölçülmüştür (Şekil 4). PPE uygulaması tek başına kontrol grubuna göre herhangi bir etki ortaya koymamıştır. Ancak kontrol grubuna göre glutamat uygulaması TNF-a mRNA ekspresyonunu anlamlı şekilde artırmıştır $\left({ }^{*} p<0,05\right)$. Bu durum glutamatın oksidatif stres ile birlikte inflamasyonuda artırdığını göstermektedir. Sadece PPE uygulaması ise glutamat uygulamasına göre istatistiksel fark oluşturmuştur $(++p<0,01)$.PPE uygulaması glutamat eksitotoksisitesine bağlı gelişen inflamasyonu önemli ölçüde azaltarak antiinflamatuar etki ortaya koymuş ve nöron hasarını önlemiştir $(+p<0,05)$.

\section{Apoptotik etkinin gösterilmesi}

Çalışmamızda kontrol grubuna göre glutamat uygulaması caspas 9 ve caspas 3 mRNA ekspresyonlarını primer nöron hücrelerinde anlamlı şekilde artırmıştır $\left({ }^{* *} p<0,01\right)$. Bu durum oksidatif stress ve inflamasyon ile birlikte hücrelerin apoptoza uğradığı ve bu şekilde ciddi toksik etki ortaya koyabileceğini göstermektedir (Şekil 5-6). Tek başına PPE uygulaması caspas 9 mRNA ekspresyonunu baskılarken caspas 3 mRNA eksprsyonu üzerinde herhangi bir etki ortaya koymamıştır. Ancak, PPE uygulamasından sonra glutamat verildiğinde PPE, glutamatın yapmış olduğu apoptotik proteinlerin gen düzeyindeki ekspresyon artışlarını önlemiş ve hücre canlılığını korumuştur $(+p<0,05)$.

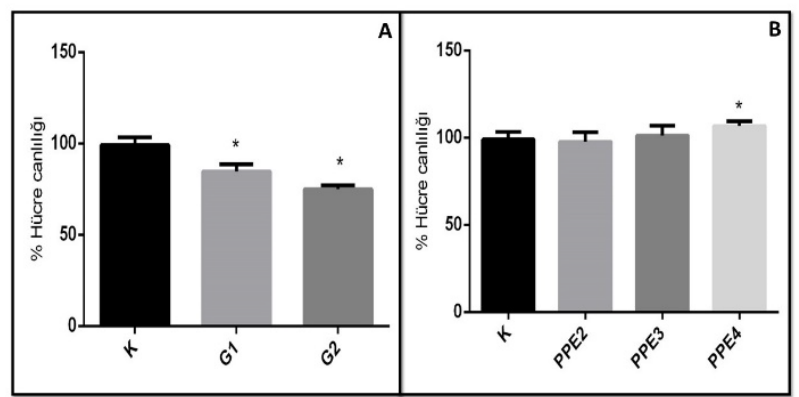

Şekil 1. A. Kontrol grubuna göre yüksek doz ve düşük doz glutamat uygulaması MTT sonuçları. B. Kontrol grubuna göre PPE uygulaması MTT sonuçları.(*kontrole göre $p<0.05$ )

G1: Düşük doz glutamat 3×10-3 Molar. G2: Yüksek doz glutamat $6 \times 10^{-3}$ Molar. K: Kontrol grubu. PPE2: $200 \mathrm{mg} / \mathrm{ml}$ nar kabuğu ekstresi. PPE3: $300 \mathrm{mg} / \mathrm{ml}$ nar kabuğu ekstresi. PPE4: $400 \mathrm{mg} / \mathrm{ml}$ nar kabuğu ekstresi.

\section{Tartışma}

Çalışmamızda güçlü antioksidan ve antikanser etkinliği olan nar kabuğu ekstresinin sıçan primer nöron kültüründe glutamat ile indüklenen nörotoksisiteye karşı koruyucu rolleri biyokimyasal ve moleküler olarak gösterilmiştir.

Merkezi sinir sisteminde nörotransmitter olarak görev alan glutamat bazal gangliyadan salınan uyarıcı nörotransmiterlerden bir tanesidir. Glutamatın aşırı miktarda aktivasyonu eksitotoksisiteye yol açmaktadır $(16,17)$. Kronik nörodejeneratif hastalıklarda eksitotoksik bulgular, uyarıcı amino asit reseptörlerindeki bir anormallik ve/veya enerji metabolizmasının bozulmasının sonucu olarak meydana gelebilmektedir. Glutamatın sinaptogenez, öğrenme ve hafızada rol oynadığı, ayrıca iskemi, epilepsi ve nörodejeneratif hastalıklar gibi patolojik pek çok durumda da etkili olduğu bilinmektedir. Aşırı miktardaki hücre dışı glutamat seviyesi, nörotransmiter reseptörlerinin aşırı uyarılması nedeniyle hücrenin sağlığı ve yaşamı üzerinde olumsuz etkilere yol açabilir. Bunun yanında, yüksek seviyedeki hücre dışı glutamat, glutamat/sistin antiporterlerin fonksiyonunu engelleyerek glutatyon oluşumunu durdurur ve sonuç olarak hücre içi serbest radikal artışı ve hücresel toksisite meydana gelir.

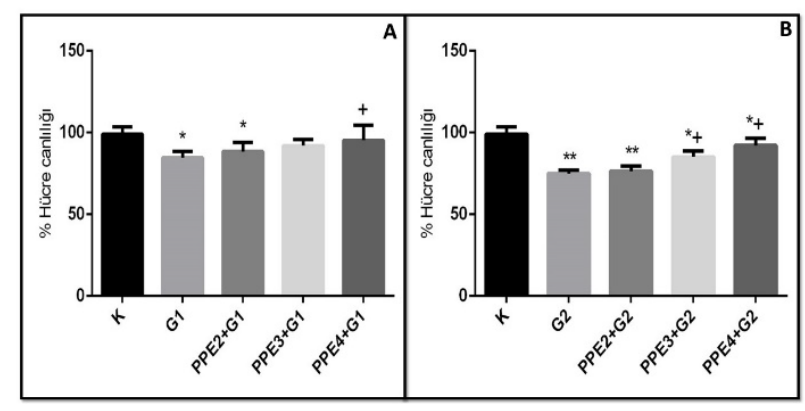

Şekil 2. A. Düşük doz glutamat uygulamasına karşı PPE uygulaması MTT sonuçları. B. Yüksek doz glutamat uygulamasına karşı PPE uygulaması MTT sonuçları. ("kontrole göre $p<0.05$, "kontrole göre $p<0.01$, toksisite grubuna göre $p<0.05)$

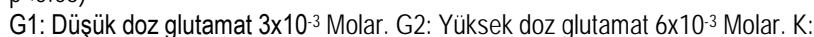
Kontrol grubu. PPE2: $200 \mathrm{mg} / \mathrm{ml}$ nar kabuğu ekstresi. PPE3: $300 \mathrm{mg} / \mathrm{ml}$ nar kabuğu ekstresi. PPE4: $400 \mathrm{mg} / \mathrm{ml}$ nar kabuğu ekstresi.

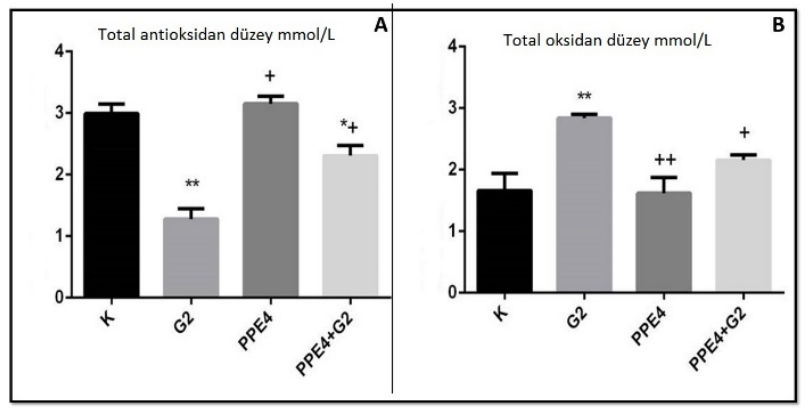

Şekil 3: A. Total antioksidan kapasite sonuçları. B. Total oksidan kapasite sonuçları. ("kontrole göre $p<0.05$, "kontrole göre $p<0.01$, toksisite grubuna göre $p<0.05,{ }^{++}$toksisite grubuna göre $p<0.01$ )

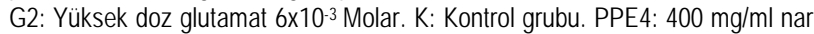
kabuğu ekstresi.

MTT hücre canlılığının belirteci olarak in vitro çalışmalarda sıklıkla kullanılmaktadır. Canlı hücrelerin mitokondrilerinde süksinat-dehidrogenaz enzimi tetrazolyum halkasını parçalayarak çözünmeyen formazan tuzları oluşturmaktadır. Oluşan formazan kristalleri canlılık oranı yüksek kültürlerde absorbans değerinin yüksek çıkmasına neden olmaktadır.Önceki yapılan çalışmalarda glutamatın sitotoksik etkisine bağlı olarak primer nöron canlılığını azalttığı gösterilmiştir(12). Çalışmamızda da glutamat uygulaması doza bağlı olarak primer nöron hücrelerinin canlılığını önemli ölçüde azaltmıştır. PPE'nin ise tek başına verildiği zaman tüm dozlarda herhangi bir toksik etki oluşturmadığı 
görülmüştür. Hatta sayısal olarak hücre proliferasyonunu artırmıştır. PPE, glutamata bağlı gelişen primer nöron hasarını önemli ölçüde önleyerek hücre canlılığını korumuştur.

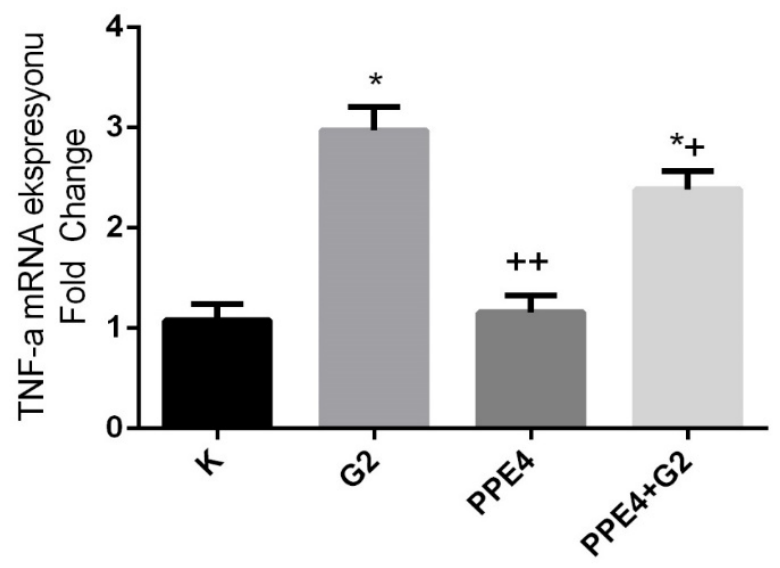

Şekil 4. TNf- a mRNA ekspresyonu sonuçları. ("kontrole göre $p<0.05$, ${ }^{*}$ kontrole göre $p<0.01$, +toksisite grubuna göre $p<0.05,{ }^{++}$toksisite grubuna göre $p<0.01$ ) G2: Yüksek doz glutamat $6 \times 10^{-3}$ Molar. K: Kontrol grubu. PPE4: $400 \mathrm{mg} / \mathrm{ml}$ nar kabuğu ekstresi.

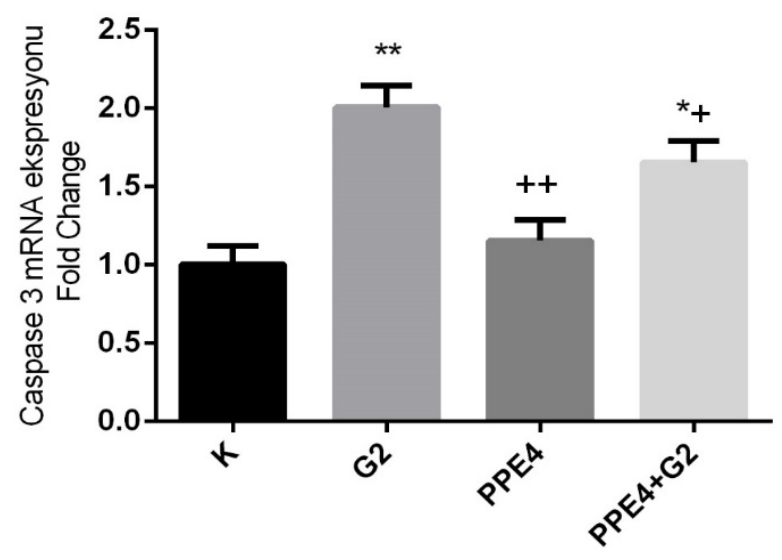

Şekil 5. Caspas 3 mRNA ekspresyonu sonuçları. ("kontrole göre $p<0.05$, **kontrole göre $p<0.01$, toksisite grubuna göre $p<0.05,{ }^{++}$toksisite grubuna göre $p<0.01)$

G2: Yüksek doz glutamat 6×10-3 Molar. K: Kontrol grubu. PPE4: 400 mg/ml nar kabuğu ekstresi.

Oksidatif stres nedeniyle artan serbest radikallerin membranda hasar oluşturarak hücreyi ölüme sürükledikleri bilinmektedir. Serbest radikallerin neden oldukları hasarı önleme mekanizması ise antioksidan savunma mekanizmasıdır. Antioksidan işleyişinin yetersiz kaldığı durumlarda serbest radikaller daha şiddetli hasar oluşturabilirler. Bu nedenle antioksidan etkinliği olan maddelerin oksidatif strese bağlı gelişebilecek hasarı önlediği düşünülmektedir (18). Yapılan araştırmada nar kabuklarının hem eczacılık hem de diğer alanlarda proantosiyanidin ve kersetol kaynağı olarak değerlendirilebileceğini ifade etmişlerdir. Buna ilaveten nar kabuğu ve nar çekirdeği ekstraktlarının antioksidan ve antimikrobiyel potansiyeli incelenmiş; nar kabuğu ekstraktının, nar danesi ekstraktından daha yüksek antioksidan kapasitesine sahip olduğu gözlemlenmiştir. Nar kabuğu ekstraktının hidroksil grubu ve süperoksit anyonunu bağlama etkisinin yüksek olduğu tespit edilmiştir $(10,19)$. Literatürde oksidatif stres ve antioksidan sistembelirteci olarak kullanılan pek çok biyokimyasal yöntem mevcuttur. Özellikle in vitro çalışmalarda toplam oksidan ve antioksidan düzeyinin belirlenmesini sağlayan TAK ve TOD ölçümleri literatürde yaygın olarak kullanılmaktadır $(20,21)$. Çalışmamızda TAK ve TOD ölçümü sonuçlarına göre tek başına PPE uygulaması toplam oksidan düzeyi etkilemezken, toplam antioksidan kapasiteyi kontrol grubuna göre artırmıştır. Ancak glutamat uygulaması oksidan düzeyi artıırken, antioksidan düzeyi de anlamlı şekilde azaltımıştır. PPE $400+G 2$ grubunda ise PPE, glutamatın etkisini önleyerek oksidatif stresin azalmasını sağlamış ve nöron hasarını korumuştur. Glutamat ile indüklenen nörotoksisitede TOD seviyesinin arttığı, TAK seviyesinin ise azaldığı önceki çalışmalarda gösterilmiştir (12).

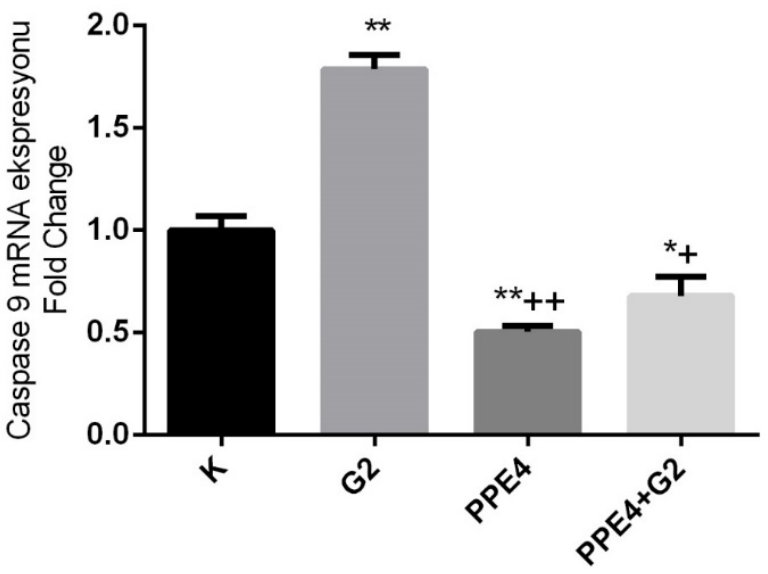

Şekil 6. Caspas 9 mRNA ekspresyonu sonuçları. ("kontrole göre $p<0.05$, "*kontrole göre $p<0.01$, +toksisite grubuna göre $p<0.05,{ }^{++}$toksisite grubuna göre $\mathrm{p}<0.01)$

G2: Yüksek doz glutamat 6×10-3 Molar. K: Kontrol grubu. PPE4: 400 mg/ml nar kabuğu ekstresi

Çalışmamız ile PPE'nin proliferatif ve oksidatif stres üzerine olan etkileri ortaya konmuştur. Buna ilaveten moleküler olarak da hasarın önemli bir göstergesi olan inflamasyonun varlığı gösterilmiştir. Toksisite durumunda ortaya çıkan oksidatif strese inflamasyonda eşlik etmekte ve hasarın şiddeti artmaktadır. İlamasyonun belirteci olarak öne çıkan TNF-a hem proinflamatuar hem de ekstrinsik apoptotik etkilidir (22). Artmış olan TNF-a makrofajlar ve monositler ile birlikte inflamatuar süreci başlatarak gelişen hasarın şiddetlenmesine yol açmakta ve iki reseptörü ile apoptozisi başlatmaktadır $(23,24)$. Yapılan eksitotoksisite çalışmaları glutamatın TNF-a üretimini artırdığını ve böylelikle hem inflamasyona hem de nöron hücrelerinin apoptozisine yol açtığı gösterilmektedir $(25,26)$. Bizim çalışmamızda da 
glutamat uygulaması kontrol grubuna göre anlamlı şekilde TNF-a ekspresyonunu indüklerken PPE uygulaması bu etkiyi önemli ölçüde düzeltmiştir. PPE'nin artmış olan TNF-a ekspresyonunu önlemesi antioksidan etkisinin yanında önemli antiinflamatuar etkilere sahip olduğunu göstermektedir. Nitekim yapılan çalışmalarda da PPE'nin antiinflamatuar etkinliği desteklenmektedir $(27,28)$. Bu yüzden PPE'nin pek çok faydalı etkiler ortaya koyduğu düşünülmektedir.

Glutamat, iyonotrobik (iGluR) ve metabotrobik (mGluR) reseptörleri üzerinden etkilerini göstermektedir. mGluR ise hücre içi enzimlerin $G$ proteini aracılı yol ile kontrolünü sağlarken iGluRise iyon kanallarını kontrol ederek MSS'de eksitotoksik nörotransmisyonu sağlar. iGluR dahilinde AMPA, NMDA ve kainat reseptörleri bulunmaktadır. Glutamatın en önemli ve majör etkili reseptörü olan NMDA bilindiği üzere glutamat eksitotoksisitesine aracılık etmektedir. Apoptotik yolaklar üzerinde yapılan bir çalışmaya göre sıçan striatal nöronları NMDA reseptör agonisti kuinolik asit ile uyarıldığında, protein yıkım enzimi olan caspaz 3 aktive olmaktadır. Caspaz 3'ün inhibitör kappa B alfa'nın yıkımına neden olarak NFkB'nin serbest kalmasını hızlandırarak çekirdeğe translokasyonunu etkilemekte ve dolaylı olarak apoptoz görünümünde ölüme neden olmaktadır. Diğer iGluR reseptör agonistleri ile indüklenen eksitotoksisitenin de benzer sonuçlar oluşturduğugörülmüştür (29). Çalışmamızda yüksek doz glutamatın caspas 9 ve 3 seviyeleri üzerinde oluşturduğu değişiklikler tespit edilmiştir. Sonuçları$\mathrm{mIz}$ incelendiğinde glutamat caspas 9 ve 3 seviyelerinde bir artışa neden olaraknöranal ölümü artırmıştı. PPE uygulaması ise glutamatın neden olduğu caspas 3 artışını anlamı şekilde baskılayarak antiapoptotik etki ortaya koymuştur. Özellikle PPE tek başına verildiğinde caspas 3 ekspresyonu üzerinde bir etki göstermezken caspase 9 ekspresyonunu kontrole göre anlamlı şekilde baskılamış ve yine glutamata bağlı artan caspase 9 ekspresyonunuda anlamlı şekilde baskılayarak anti apoptotik etki ile nöronal canlıı̆ı korumayı başarmıştır. Önceki çalışmalarda PPE'nin antiapoptotik etki oluşturduğu ve caspas proteinlerinin inhibisyonu ile ototoksisite gelişimini önlediği gösterilmiş̧tir (30).

Sonuç olarak PPE güçlü antioksidan, antiinflamatuar ve antiapoptotik etkilerinden dolayı glutamat gibi önemli bir nötotranasmittere bağlı gelişen nöronal hasara karşı koruyucu etki göstermiştir. Bu yüzden PPE'nin sağlık alanındaki önemi giderek artmaktadır. Ancak çalışmamızın ileri deneysel ve klinik çalışmalar ile desteklendikten sonra gelecekte PPE'nin farmakolojik bir ajan olarak kullanılması kaçınılmaz olacaktır.

\section{Kaynaklar}

1. Gölükcü M, Toker R, Tokgöz H. Hasat zamanının nar suyunun şeker ve organik asit bileşimleri üzerine etkisi. Gıda. 2011; 36(6): 355341.

2. İsmail T, Sestili P, Akthar S. Pomegranate peel and fruit extracts: A review of potential anti-inflammatory and anti-infective effects. Journal of ethnopharmacology. 2012; 143(2): 397-405.

3. Topkaya C. Nar kabuğu tozu ilavesinin keklerin besinsel, duyusal ve mikrobiyolojik özelliklerine etkisi. Yüksek lisans tezi, Denizli, Pamukkale Üniversitesi Fen Bilimleri Enstitüsü, 2017.

4. Karakaya S ve EI SN. Total Phenols and Antioxidant Activities of Some Herbal Teas and In Vitro Bioavailability of Black Tea Polyphenols. GOÜ. Ziraat Fakültesi Dergisi. 2006; 23(1): 1-8.

5. Özkan G, Baydar G. A Direct RP-HPLC Determination of Phenolic Compounds in Turkish Red Wines. Akdeniz Üniversitesi Ziraat Fakültesi Dergisi. 2006; 19(2): 229-234.

6. Chandra R, Jadhav VT, Shrama J. Global scenario of pomagranate (Punica granatum L.) culture with special reference to India. Fruit Veg Cereal Sci 2010;4(2): 17-8.

7. Nizamlıoğlu NM, Nas S. The phenolic compounds in vegetables and fruit; structures and their importance. Electronic Journal of Food Technologies. 2010; 5(1): 20-35.

8. Yıldırım AN, Yııdııım F, Şan B, Polat M, Sesli Y. Variability of phenolic composition and tocopherol content of some commercial Almond cultivars. Journal of Applied Botany and Food Quality. 2016; 89(1): 163-170.

9. Negi PS, Jayaprakasha GK, Jena BS. Antioxidant and antimutagenic activities of pomegranate peel extracts. Food Chemistry. 2003; 80(3): 393-397.

10. Özkal N, Dinç S. Valuation of The Pomegranate (Punica granatum L.) Peels From The Standpoint of Pharmacy. Ankara Üniversitesi Eczacılık Fakültesi Dergisi. 1993; 22(1): 21-29.

11. Aydın ÖF, Kurne A, Karabudak R. MS patogenezinde basamaklarII:nörodejenerasyonda biyolojik göstergeler, sodyum kanalları ve glutamatın rolü. Türk nöroşirurji dergisi. 2006; 12(2): 98-105.

12. Gündoğdu G, Taghizadehghalehjoughi A, Çiçek B, Şenol O, Nalcı KA, Demirkaya AK ve ark. Glutamat Eksitotoksisitesi Oluşturulan Primer Kortikal Nöron Kültürlerinde Parietinin Nöroprotektif Etkisinin İncelenmesi. Atatürk Üniversitesi Vet. Bil. Derg. 2018; 13(2): 165-173.

13. Cetin $D$, Hacimufuoglu A, Tatar A, Turkez $H$, Togar $H$. The in vitro protective effect of salicylic acid against paclitaxel and cisplatin-induced neurotoxicity. Cytotechnology. 2016; 68(4): 1361-1367.

14. Yayla M, Cetin D, Demirbağ Ç, Kılıçle Aksu P. Nar Kabuğu Ekstresinin Sıçanlarda Paklitakselle İndüklenen Primer Nöron Hasarına Karşı Koruyucu Etkisi. Kafkas J Med Sci 2018; 8(3):149-157.

15. Palabiyik SS, Karakus E, Halici Z, Cadirci E, Bayir Y, Ayaz G, Cinar I. The protective effects of carvacrol and thymol against paracetamol-induced toxicity on human hepatocellular carcinoma cell lines (HepG2). Human \& Experimental Toxicology. 2016; 35(2): 12521263.

16. Meldrum BS. Glutamate as a neurotransmitter in the brain: review of physiology and pathology. The Journal of Nutrition. 2000; 130(4): 1007-15.

17. Sharma A, Kaur G. Tinospora cordifolia as a potential neuroregenerative candidate against glutamate induced excitotoxicity: an in vitro perspective. BMC Complement Altern Med. 2018; 18(1): 268271.

18. Motor S, Ozturk S, Ozcan O, Gurpinar AB, Can Y, Yüksel R et al. Evaluation of total antioxidant status, total oxidant status and oxidative stress index in patients with alopecia areata. Int J Clin Exp Med. 2014; 7(4):1089-93.

19. Kanatt RS, Chander R, Sharma A. Antioxidant and antimicrobial activity of pomegranate peel extract improves the shelf life of chicken products. International Journal of Food Science \& Technology. 2010; 45(2): 216-222.

20. Aslan R, Kutlu R, Civi S, Tasyurek E. The correlation of the total antioxidant status (TAS), total oxidant status (TOS) and paraoxonase activity (PON1) with smoking Author links open overlay panel. Clin Biochem. 2014; 47(6):393-7. 
21. Abundan M, Çelik M, Almaz V, Geter S, Selek S, Koca B et al. Evaluation of S-100B and Oxidative Status before and after Treatment in Children with Bacterial Meningitis. Klin Derg. 2012; 25(2): 67-70.

22. Meloni F. Tumor necrosis factor a. Biological aspects. Gior Itali di Chemi 1989; 40(36):29-37.40.

23. MacEwan D J. TNF ligands and receptors - a matter of life and death. Brit J Pharm 2002; 135(4): 855-5.

24. MacEwan D J. TNF receptor subtype signalling: differences and cellular consequences. Cell Sig 2002;14(6):477-92.

25. Binnetoğlu D, Yayla M. Agmatine and Glutamate Induced Primary Neuron Damage: In Vitro Study. International Research Journal of Pharmacy and Medical Sciences. 2018; 2(1): 52-56.

26. Takeuchi H1, Jin S, Wang J, Zhang G, Kawanokuchi J, Kuno R, Sonobe $Y$, Mizuno T, Suzumura A. Tumor necrosis factor-alpha induces neurotoxicity via glutamate release from hemichannels of activated microglia in an autocrine manner. J Biol Chem. 2006; 281(30): 21362-8.

27. Soojin $P$, Jin KS, Jun Yup K, Hwa-Jin S, YoungMi K, Yong CB. AntiInflammatory Effects of Pomegranate Peel Extract in THP-1 Cells Exposed to Particulate Matter PM10. Evid Based Complement Alternat Med. 2016; 16(3):1-11.

28. Maressa CM, Jocelem MS, Milena T, Danilo M, Patricia B, Hudson $\mathrm{SB}$ et al. Neuroprotective Effects of Pomegranate Peel Extract after Chronic Infusion with Amyloid- $\beta$ Peptide in Mice. PLoS One. 2016;11(11): e0166123.

29. Tüfekçi MA, Ersoy Tunalı N. Huntington Hastalığında Toksisite Mekanizmaları ve NMDAR-Aracılı Eksitotoksisitede Poliaminlerin Rolü. Turkiye Klinikleri J Med Sci.2012; 32(1): 201-213.

30. Shuangyue L, Xiao Z, Meiling S, Tao X, Aimei W. FoxO3a plays a key role in the protective effects of pomegranate peel extract against amikacin-induced ototoxicity. Int J Mol Med. 2017; 40(1):175181. 